\title{
The Effect of Tax Incentives Practices on Sustainability of Micro, Small and Medium Enterprises in Ethiopia During the Outbreak of Corona Virus Pandemic
}

Kanbiro Deyganto Orkaido ( $\sim$ kanbiro.orkaido@gmail.com )

Dilla University https://orcid.org/0000-0001-8412-1990

Bekele Youna Beriso

Pharma College

\section{Research}

Keywords: Micro, Small and Medium Sized Enterprise, Tax incentives practice, Suitability, Corona Virus Pandemic

Posted Date: December 18th, 2020

DOI: https://doi.org/10.21203/rs.3.rs-129777/v1

License: @ (i) This work is licensed under a Creative Commons Attribution 4.0 International License. Read Full License 


\section{Abstract}

Purpose: The aim of this study was to identify the effect of tax incentive practise on sustainability of MSMEs during outbreak of corona virus pandemic in Ethiopia.

Design/methodology/approach: In order to achieve this objective, the researchers have employed quantitative research approach with explanatory research design in which six hypotheses have been tested. The primary data was collected from 300 respondents using structured questionnaires. Multiple regression model was employed to identify the effect of tax incentives on sustainability of MSMEs in Ethiopia.

Findings: According to the regression analysis, this study revealed that tax holiday, tax allowance, reduction in tax rate, accelerated depreciation, loss carry forward and tax exemption have positive and statistically significant effect on the sustainability of the MSMEs. Based on the finding of the study was concluded that the existence of tax incentive practice has positive contribution to sustainability of the micro, small and medium sized enterprise.

Research limitations/implications: The current study was geographically focus on Ethiopia by considering the micro, small and medium sized enterprises sector. The subject wise was focused on the effect of the tax incentives:(tax holiday, tax allowance, tax exemption, and accelerated depreciation, reduction in tax rate, and loss carry forward) and on the sustainability of MSMEs. The study used primary data which is limited to a year of 2020. It might be improved in the future if other researchers incorporate large firms in the country and uses secondary data for analysis.

Practical implications: To survive, micro, small and medium scale enterprises need the support from the government in the form of tax incentives. The role of tax incentives in enhancing the growth of micro, small and medium sized enterprises is very significant on the sustainability of MSMEs as well as the economy as a whole. Hence, the findings and recommendations of the current study might serve as an ingredient and be informative to the policy makers on MSMEs sector. It might also give a general insight to the policy makers, academician and professional groups of society and the public at large with regard to the role of effect of tax incentives on the sustainability and growth of MSMEs during outbreak of coronavirus.

Originality/value: This study contributes to empirical evidence about the effect of tax incentives practices on sustainability of micro, small and medium enterprises in Ethiopia by considering tax incentive practice in terms of tax holiday, tax allowance, reduction in tax rate, accelerated depreciation, loss carry forward and tax exemption. As tax incentives theories supported the findings of this study, we have concluded that tax incentive practices provided by government have positive contribution for the sustainability and growth of micro, small and medium sized enterprises in Ethiopia

\section{Introduction}

Micro, Small and Medium -Sized Enterprise (MSMEs) are considered as an engine for world economy but they are being hit hardest by the fall-out of the corona virus pandemic (Jyoti, Yadav, and Neelam Gulati, 2019). Like many developing counties, in Ethiopia, the pandemic led to a massive damage on economic activities in general and MSME's in particular following restriction on human mobility by the government and stay-at-home advice by ministry of health. These actions and advice, then, has adversely affected both the supply and demand side of MSME's operation (K. Lemi. M. Bogale. \& W. Mengesha, 2020). Specifically, the pandemic's negative consequences on MSME's include raw material supply was stopped, shortage of workers happened, shortage of working capital created, their operational cost increased, and decline in consumers consumption of products of MSMEs. The labor market impact of the COVID-19 pandemic reveals the devastating effect on workers in the informal economy and on hundreds of millions of enterprises worldwide (ILO 2020). As a result, MSME's contribution to national GDP, creation of employment opportunity, and other benefits are being hampered.

Therefore, solutions are needed to give them the support they need to survive and continue to contribute to the global economy (R. D. Olana, 2020). Tax incentives are the government measure in place intended to encourage MSMEs enterprises by deduction, exclusion, exemption from a tax liability for a certain period to sustain survival and growth (K. Lemi. M. Bogale. 
\&W. Mengesha. (2020). Keeping the above view in mind, properly and well-designed tax incentive is crucial for development of micro, small and medium sized enterprises for purpose of job creation, poverty reduction and GDP growth for global economy especially during outbreak of corona virus pandemic. There are several theories that support the study of taxation as a discipline, only few can be directly traced to tax incentives practices. These are: Laffer curve theory; Classical theory, Neoclassical theory; and New Growth (endogenous) theory. But, Laffer curve theory is the most appropriate to this study which argue that it is possible to generate higher revenues by granting tax incentives for MSMEs.

So, micro, small and medium scale enterprises have to be supported by government measures like tax incentive practices to survive. Prior studies by Atawodi O.W. \& Ojeka1.S.(2012); Oniha. K. (2018); Gokhberg L., Kitova G., Roud V. (2014); K. Lemi. M. Bogale. \& W. Mengesha. (2020 were evidenced that tax incentives practices have positive and statistically significant effect on growth of MSMEs. As far as knowledge of researcher is concurred few research has been conducted on related topic in Ethiopia without considering the effect of tax incentives practice on sustainability of micro, small and medium sized enterprises while existence of corona virus outbreak in Ethiopia. This is why the researchers motivated to conduct this research work and by using the aforementioned research gaps the researchers would identify the effect five tax incentive indicators such as tax holiday, tax allowance, accelerated depreciation, reduced tax rate, loss carry forward and tax exemption on the sustainability of MSMEs in Ethiopia.

\section{Research Objectives}

The general objective of this study was identify the effects of tax incentives practices on sustainability of micro, small and medium sized enterprises operated in Ethiopia during outbreak of COVID-19 pandemic. Specifically, this was addressed the following objectives:

- To identify the effect of tax holiday on sustainability of MSMEs

- To investigate the impact of tax allowance on sustainability of MSMEs

- To examine the effect decrease in tax rate has on sustainability of MSMEs

- To identify the impact of accelerated depreciation on sustainability of MSMEs

- To investigate the effect of loss, carry forward on sustainability of SMEs

- To investigate the effect of tax exemption on sustainability of SMEs

\section{Research Hypotheses}

After critically reviewing the empirical studies, the researcher developed the following hypotheses:

H1: Tax holiday has positive and statistically significant effect on the sustainability of MSMEs

H2: Tax Allowance has positive and statistically significant effect on the sustainability of MSMEs

H3: Decrease in Tax rate has positive and statistically significant effect on the sustainability of MSMEs

H4: Accelerated depreciation has positive and statistically significant effect on sustainability of MSMEs

H5: Loss carry forward has positive and statistically significant effect on sustainability of MSMEs

H6: Tax exemption has positive and statistically significant effect on sustainability of MSMEs

\section{Scope of the Study}

The current study would geographically focus on Ethiopia by considering the micro, small and medium sized enterprises sector. The subject wise was focused on the effect of the tax incentives:(tax holiday, tax allowance, and accelerated 
depreciation, reduction in tax rate, loss carry forward and tax exemptions) and on the sustainability of MSMEs during existence of COVID-19. To address the objectives of the study, the study used primary data which is limited to a year of 2020.

\section{Need of the Study}

To survive, micro, small and medium scale enterprises need the support from the government in the form of tax incentives. The role of tax incentives in enhancing the sustainability of small and medium sized enterprises has significant on the sustainability of the firm as well as the economy as a whole. Hence, the findings and recommendations of the current study will serve as an ingredient and be informative to the policy makers on MSMEs sector. It will also give a general insight to the policy makers, academician and professional groups of society and the public at large with regard to the role of effect of tax incentives on the sustainability of MSMEs during outbreak of coronavirus.

\section{Literature Review}

\section{Coronavirus Disease}

In early 2020, after a December 2019 outbreak in China, the World Health Organization identified SARS-CoV-2 as a new type of coronavirus. The outbreak quickly spread around the world. COVID-19 is a disease caused by SARS-CoV-2 that can trigger what doctors call a respiratory tract infection. It can affect your upper respiratory tract (sinuses, nose, and throat) or lower respiratory tract (windpipe and lungs). It spreads the same way other coronaviruses do, mainly through person-to-person contact. Infections range from mild to deadly. The World Health Organization (WHO) on March 11 declared COVID-19 a pandemic, pointing to the over 118,000 cases of the coronavirus illness in over 110 countries and territories around the world and the sustained risk of further global spread. An epidemic refers to an uptick in the spread of a disease within a specific community. By contrast, the WHO defines a pandemic as global spread of a new disease, though the specific threshold for meeting that criteria is fuzzy. The term is most often applied to new influenza strains, and the CDC says it's used when viruses "are able to infect people easily and spread from person to person in an efficient and sustained way" in multiple regions. The declaration refers to the spread of a disease, rather than the severity of the illness it causes (WHO, 2020).

Coronavirus disease (COVID-19) is an infectious disease caused by a newly discovered coronavirus. Most people who fall sick with COVID-19 will experience mild to moderate symptoms and recover without special treatment. The virus that causes COVID-19 is mainly transmitted through droplets generated when an infected person coughs, sneezes, or exhales. These droplets are too heavy to hang in the air, and quickly fall on floors or surfaces. You can be infected by breathing in the virus if you are within close proximity of someone who has COVID-19, or by touching a contaminated surface and then your eyes, nose or mouth. A coronavirus is a kind of common virus that causes an infection in your nose, sinuses, or upper throat. Most coronaviruses aren't dangerous (D. Olani, 2020).

Corona Virus emerged in Wuhan, China, spread across the world infecting more than 6.1 million and causing death of more than 371, 857 people as of June 1, 2020. In Africa, since the first case was reported in Egypt, the virus has spread to 53 countries within weeks. As of June 1, 2020, more than 146, 996 cases and 4, 222 deaths were reported (CDC, 2020). In Ethiopia, total of 1,257 cases and 12 deaths were reported by Ministry of Health on June 1, 2020(MOH, 2020) and Community Health Institute (2020). The outbreak of COVID-19 pandemic has disturbed the political, economic, social, religious and financial structure of the world.

\section{Theories of Tax Incentives}

Tax incentives are the measures taken by government for encouraging the growth and survival business enterprises in the form of tax holiday, tax allowance, accelerated depreciation, reduction in tax rate and loss carry forward (Melese, 2013). Currently, most developing countries introduce massive tax incentives program in order to attract capital and support economic growth especially in order to reduce the effect of COVID-19. There are several theories support the study of taxation as a discipline, only few can be directly traced to tax incentives practices. These are: Laffer curve theory; Classical theory, Neo- 
classical theory; and New Growth (endogenous) theory. But, Laffer curve theory is the most appropriate to this study which argue that it is possible to generate higher revenues by granting tax incentives for MSMEs.

This part will cover the theories that support the relationship between the tax incentives and growth of SMEs. Several theories support the study of taxation as a discipline, only few can be directly traced to tax incentives. These are: Laffer curve theory; Classical theory, Neo-classical theory; and New Growth (endogenous) theory. But, Laffer curve theory is the most appropriate to this study which argue that it is possible to generate higher revenues by cutting tax rates.

i. Laffer curve theory: Laffer curve theory was originated in 1974 by supply-side economist Arthur Laffer to show the relationship between tax rates and the amount of tax revenue collected by governments. The curve is used to illustrate Laffer's argument that sometimes cutting tax rates can increase total tax revenue. Laffer curve explained that lower tax rate could encourage an additional output and it would increase income, which builds bigger tax base in an economy by improving the growth of business enterprises (Latif et al. 2019). This theory supports idea of tax incentives has positive and statistically significant effect on the growth of MSMEs" and the whole idea of tax incentive is all about ways of reducing taxes for businesses and individuals in exchange for specific desirable actions or investments on their parts. The researcher therefore used Laffer curve theory as grand theory because it provides an economic justification for the politically popular policy of cutting tax rates.

ii. Classical Theory: This theory was developed shortly after the birth of western capitalism and the Industrial Revolution. The Originator of classical theory was Adam Smith ((1776) who was an 18th-century Scottish economist, philosopher, and author, and is considered the father of modern economics. The main idea of the Classical school was that markets work best when they are left alone, and that there is nothing but the smallest role for government. The approach is firmly one of laissez-faire and a strong belief in the efficiency of free markets to generate economic development. This theory was criticized for its assumption of the equal use of labor and capital in production, given birth to neo-classical movement of the 1950s.

iii. Neo-classical Theory: Alfred Marshall was an English economist (1842-1924), and the true founder of the neoclassical school of economics, which combined the study of wealth distribution of the classical school with marginalize of the Austrian School and the Lausanne School Robert Solow and Trevor Swan first introduced the neoclassical growth theory in 1956 . The theory states that economic growth is the result of three factors-labor, capital, and technology. While an economy has limited resources in terms of capital and labor, the contribution from technology to growth is boundless. The neoclassical investment theory thus suggests that tax incentives encourage growth of established firms through reinvestments and also. The classical theory emphasizes on production of goods and services as the key focus of economic analysis. Whereas, neoclassical economics focuses on how individuals operate within an economy. As such, the neoclassical school emphasizes the exchange of goods and services as the key focus of economic analysis.

iv. New Growth Theory: Economist Paul Romer has developed a theory of economic growth with "endogenous" technological change. The core idea Endogenous growth theory maintains that economic growth is primarily the result of internal forces, rather than external ones. It argues that improvements in productivity can be tied directly to faster innovation and more investments in human capital from governments and private sector institutions. Provision of tax incentives is in the form of either tax relief or cash grants. International experience shows that such incentives play only a minor role in investment decisions. Firms make investment decisions based on many factors including projections of future demand, certainty about future government policy, prevailing interest rates and moves by competitors. In general, neo-classics see incentives as "nice

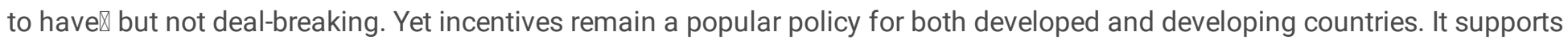
that good tax incentive policy that designed by a country improves the growth of MSMEs.

\section{Empirical Review of Related Studies}

Emerging economies have introduced tax incentives for various reasons. In some countries in transition, such instruments may be seen as a counterweight to the investment disincentives inherent in the general tax system. In other countries, the incentives are intended to offset other disadvantages that investors may face, such as a lack of infrastructure, complicated

Page 5/16 
and antiquated laws, bureaucratic complexities and weak administration. In Ethiopia, with the increase in the number of people infected with COVID-19, the government declared state of emergency aiming to curb the spread of the virus in the country. The state of emergency puts restriction on travel and human mobility which caused adverse effect on economy and businesses particularly micro and small sectors. This effect requires more research based evidence that shows the extent to which MSME's are affected. Although reports are coming out from different media outlets, further evaluation is required to reveal the effect of the unprecedented pandemic on the MSME's and provide the possible solutions. So far no study is conducted on this issue. Now, it is time to respond the mentioned gap through rapid assessment of the effect of Corona Virus on MSME's operation and provide insight for decision makers in the sector and for researchers to conduct further investigation (K. Lemi. M. Bogale. \& W. Mengesha. (2020). Different studies addressed the topic in the world, Africa and Ethiopia summarized that tax incentive indicators such as tax holiday, investment allowance, tax rate, tax credit, accelerated depreciation and loss carry forward on the sustainability and growth of Small and medium sized enterprises. The empirical findings has summarized as follow:

Table 1: Summary of empirical review on effect of Tax Incentives on the growth of SMEs

\begin{tabular}{|c|c|c|c|c|}
\hline $\begin{array}{l}\text { Serial } \\
\text { Number }\end{array}$ & $\begin{array}{l}\text { Variable } \\
\text { Name }\end{array}$ & Empirical Studies & $\begin{array}{l}\text { Theory Supported The } \\
\text { Idea }\end{array}$ & $\begin{array}{l}\text { Effect On } \\
\text { Sustinability } \\
\text { Of Msmes }\end{array}$ \\
\hline 1 & Tax holiday: & $\begin{array}{l}\text { Atawodi O.W. \& Ojeka1.S (2012); Samuel } \\
\text { (2015) and Twesige and Gasheja (2019) and }\end{array}$ & New Growth theory: & Positive (+) \\
\hline 2 & $\begin{array}{l}\text { Tax } \\
\text { Allowance }\end{array}$ & $\begin{array}{l}\text { Schellhase J.(2017); Atawodi O.W. \& Ojeka1.S. } \\
\text { (2012); Twesige and Gasheja. (2019) }\end{array}$ & $\begin{array}{l}\text { Laffer curve theory \& } \\
\text { New Growth theory: }\end{array}$ & Positive (+) \\
\hline 3 & $\begin{array}{l}\text { Reduction in } \\
\text { Tax Rate }\end{array}$ & $\begin{array}{l}\text { Atawodi O.W. \& Ojeka1.S.(2012); Twesige and } \\
\text { Gasheja. (2019 }\end{array}$ & $\begin{array}{l}\text { Laffer curve theory, } \\
\text { neoclassical \& New } \\
\text { Growth theory: }\end{array}$ & Positive (+) \\
\hline 4 & $\begin{array}{l}\text { Accelerated } \\
\text { Depreciation }\end{array}$ & $\begin{array}{l}\text { Atawodi O.W. \& Ojeka1.S.(2012); Twesige and } \\
\text { Gasheja. (2019); Schellhase .J. (2017); Oniha.K. } \\
\text { (2018; }\end{array}$ & $\begin{array}{l}\text { Laffer curve theory \& } \\
\text { New Growth theory }\end{array}$ & Positive (+) \\
\hline 5 & $\begin{array}{l}\text { Loss carry } \\
\text { forward }\end{array}$ & $\begin{array}{l}\text { Atawodi O.W. \& Ojeka1.S.(2012); Twesige and } \\
\text { Gasheja, 2019; Oniha. K. (2018); Wangeci and } \\
\text { Kaplelach (2018) }\end{array}$ & $\begin{array}{l}\text { New Growth theory, } \\
\text { neoclassical and Laffer } \\
\text { curve theory }\end{array}$ & Positive (+) \\
\hline 6 & $\begin{array}{l}\text { Tax } \\
\text { exemption }\end{array}$ & $\begin{array}{l}\text { Atawodi O.W. \& Ojeka1.S.(2012); Damtew. M. } \\
\text { (2014); Kassahun .S. (2016), N. Francis. (2016); }\end{array}$ & $\begin{array}{l}\text { New Growth theory, } \\
\text { neoclassical and Laffer } \\
\text { curve theory }\end{array}$ & Positive (+) \\
\hline
\end{tabular}

Source: own development based on empirical review (2020)

\section{Conceptual Framework}

Theoretical framework explains the entire research briefly, for this study, there are five explanatory variables including tax holiday, tax allowance reduction in tax rate, accelerated depreciation, loss carry forward and tax exemption as explanatory variables and the sustainability of MSMEs as dependent variable.

\section{Research Methodology}

\section{Description of the Study Area}

The study examined the effect of tax incentives on the growth of micro, small and medium enterprises will be conducted on MSMEs licensed and operated business in Ethiopian in two federal administrative cities such as Addis Ababa and Dire Dawa 
and ten (10) regions such as Afar, Amhara, Benishangul-Gumuz, Gambela, Harari, Oromia, Somali, Southern Nations, Nationalities, and Peoples' Region, Tigray and Sidama reginal states so as to provide the policy direction that boosts the growth of MSMEs through well designed tax incentive practice in Ethiopia.

\section{Research Design:}

The researchers will employee explanatory research design because, the objectives of the study is to identify the effects of tax incentives on the growth of MSMEs in Ethiopia.

3.3 Research Approach: The research approach that was employed in this study will be quantitative research approach due to quantitative nature of data.

\section{Target Population:}

Target population could be 2,490,645 Micro, Small and Medium Sized Enterprises (MSMEs) licensed operated in Ethiopia as of May, 2020.

3.5 Sampling Techniques and Sample Size: sampling technique deployed for the study will be probability which is stratified sampling techniques.

Sample size will be $n=(2,490,645) /\left(1+(0.05)^{\wedge} 2 \star 2,490,645\right)=400$ obtained using formula of (Yamane, 1967).

\section{Data Collection Instruments:}

to collect appropriate and sufficient data for the study structured questionnaire were used.

\section{Variables:}

The Dependent variable is the sustainability of MSMEs and independent variables are tax holiday, investment allowance, tax rate, tax credit, accelerated depreciation and loss carry forward.

\section{Econometric model Specification:}

To examine the effect of tax incentives on the sustainability status of MSMEs, the multiple regression model has been employed to observe the relation of each tax incentive parameter with the growth of MSMEs (number of employees due to tax incentives provided to the enterprises for last six months during existence of COVID-19). Due to fact that this is discrete variable, binary logistic (logit) regression model is appropriate.

\section{Reliability Tests:}

To carry out the reliability analysis, Cronbach's Alpha (a) is the most common measure of scale reliability and a value greater than 0.7 is very acceptable. Besides, Cronbach's alpha reliability value (a) greater than 0.6 is also acceptable. Data collected from pilot test was analyzed using SPSS (Statistical Package for Social Sciences) version 21.0

\section{Validity Tests:}

The validity of the questionnaire was used to determine through face, content and construct validity. First, the questions will be framed in such a manner that it was easily understood and exactly conveyed its sense and purpose to the respondents. Moreover, the draft questionnaire will be given to academic staff to view it in the light of the research objectives, its relevance, the adequacy of the questionnaire items, and question coverage. The construct validity for internal consistency of variables was captured by Cronbach's coefficient alpha.

\section{Ethical Considerations:}


The ethical considerations given attention by the researchers and enumerators while conducting the research that includes voluntary participation, no harm would to participants, anonymity and confidentiality, not deceiving the subjects and privacy of participants. The finding of this study will encourage the sustainability of MSMEs other than harming them.

\section{Methods of Data Analysis:}

After accomplishment of data collection procedure, it was classified as per each variable; the qualitative data was coded to be measured quantitatively. In this research, both descriptive and inferential statistics will make with the help SPSS version 21.0.

\section{Results And Discussion}

\section{Response Rate}

This part deals with analysis and discussion of data collected from 300 respondents out of 400 sample respondents from different regions in Ethiopia. The response rate was $75 \%$ which implies almost all respondents have been take part in the process of data collection. Then, the analysis of the data was based on the questionnaires collected using SPSS version 20.0 . The first section of the analysis concerns about personal information of respondents, followed by reliability and validity test of the questionnaire, descriptive statistics person correlation matrix, linear regression model assumptions, regression analysis, hypotheses testing and summary of chapter four. This has done as follow:

\section{Reliability Validity Test:}

In current research, the researcher employed Cronbach's Alpha (a) which is the most common measure of scale reliability and a value greater than 0.7 is very acceptable. This has tested as follow:

\section{Table 2: Reliability Test of the Variables}

\begin{tabular}{|ll|}
\hline Cronbach's Alpha & N of Items \\
\hline 0.947 & 44 \\
\hline
\end{tabular}

Source: Survey data, 2020

This indicates that all the variables under consideration accounts above the scientifically accepted threshold, therefore the study are reliable under this circumstance. Compared with the minimum value of alpha 0.70 advocated by Cronbach's (1951), then the responses generated for all of the variables 'used in this research were reliable enough for data analysis. This implies that the data incorporated in SPSS is reliable. The validity of the questionnaire was determined through face validity. First, the questions were framed in such a manner that it can be easily understood and exactly conveyed its sense and purpose to the respondents. Moreover, the draft questionnaires were given to academic staff to view it in the light of the research objectives, its relevance, the adequacy of the questionnaire items, and question coverage. Then pilot test of 10 questions was given to respondents that do not included in the final data analysis.

\section{Summary of Descriptive Statistics}

Descriptive statistics are very important because if we simply presented our raw data it would be hard to visualize what the data was showing, especially if there was a lot of it. Descriptive statistics therefore enables us to present the data in a more meaningful way, which allows simpler interpretation of the data. In this study, descriptive statistics were analyzed as follow:

\section{Table 3: Summary of Descriptive Statistics}




\begin{tabular}{|llllll|}
\hline Variables & N & Minimum & Maximum & Mean & Std. Deviation \\
\hline Sustainability of MSMEs & 300 & 1.00 & 5.00 & 2.6700 & 1.20246 \\
\hline Tax holiday & 300 & 1.00 & 5.00 & 2.6000 & 1.11541 \\
\hline Tax Allowance & 300 & 1.00 & 5.00 & 3.1000 & 1.32509 \\
\hline Reduction in Tax Rate & 300 & 1.00 & 5.00 & 3.2804 & .96692 \\
\hline Accelerated Depreciation & 300 & 1.00 & 5.00 & 2.9980 & .75470 \\
\hline Loss Carry Forward & 300 & 1.00 & 5.00 & 2.8300 & 1.24348 \\
\hline Tax exemption & 300 & 1.00 & 5.00 & 2.8700 & .96759 \\
\hline
\end{tabular}

Sources: Survey data, 2020

Sustainability of MSMEs was the dependent variable of this study. The Performance of MSMEs is dependent variable has overall mean of the variable was 2.6700 with standard deviation of 1.20246 a maximum of 5 and a minimum of 1 Likert scale values. The standard deviation value of 1.20246 was indicates that there was variation of actual responses from the mean. With regard to other variables the tax holiday 2.6000 with (SD) 1.11541, tax Allowance of mean 3.1000, (SD) of 1.32509, Reduction in Tax Rate 3.2804 with SD of 0.96692, Accelerated Depreciation 2.9980 with SD 0.75470, Loss Carry Forward .8300 with SD of 1.24348 and tax exemption with 2.870 with SD .96759 have the overall mean and standard deviation respectively. In short, all variables incorporated in the model have moderate contribution to the response variable sustainability of MSMEs.

\section{Pearson Correlation Matrix}

Correlation analysis measures the relationship between two items. The correlation matrix for this study was computed as follow:

\section{Table 4: Pearson Correlation Matrix of the Variables}




\begin{tabular}{|c|c|c|c|c|c|c|c|c|}
\hline Variables & & $\begin{array}{l}\text { Sustainability } \\
\text { of MSMEs }\end{array}$ & $\begin{array}{l}\text { Tax } \\
\text { holiday }\end{array}$ & $\begin{array}{l}\text { Tax } \\
\text { Allowance }\end{array}$ & $\begin{array}{l}\text { Reduction } \\
\text { in Tax } \\
\text { Rate }\end{array}$ & $\begin{array}{l}\text { Accelerated } \\
\text { Depreciation }\end{array}$ & $\begin{array}{l}\text { Loss } \\
\text { Carry } \\
\text { Forward }\end{array}$ & $\begin{array}{l}\text { Tax } \\
\text { exemption }\end{array}$ \\
\hline \multirow[t]{3}{*}{$\begin{array}{l}\text { Sustainability } \\
\text { of MSMEs }\end{array}$} & $\begin{array}{l}\text { Pearson } \\
\text { Corr. }\end{array}$ & 1 & $.350^{\star \star}$ & $.153^{\star \star}$ & $.257^{\star \star}$ & .067 & $.352^{\star \star}$ & $.368 * \star$ \\
\hline & $\begin{array}{l}\text { Sig. (2- } \\
\text { tailed) }\end{array}$ & & .000 & .008 & .000 & .249 & .000 & .000 \\
\hline & $\mathrm{N}$ & 300 & 300 & 300 & 300 & 300 & 300 & 300 \\
\hline \multirow[t]{3}{*}{ Tax holiday } & $\begin{array}{l}\text { Pearson } \\
\text { Corr. }\end{array}$ & $.350^{\star \star}$ & 1 & $.285^{\star \star}$ & $.132^{\star}$ & .064 & $-.129^{*}$ & $-.262^{\star \star}$ \\
\hline & $\begin{array}{l}\text { Sig. (2- } \\
\text { tailed) }\end{array}$ & .000 & & .000 & .022 & .266 & .026 & .000 \\
\hline & $\mathrm{N}$ & 300 & 300 & 300 & 300 & 300 & 300 & 300 \\
\hline \multirow[t]{3}{*}{$\begin{array}{l}\text { Tax } \\
\text { Allowance }\end{array}$} & $\begin{array}{l}\text { Pearson } \\
\text { Corr. }\end{array}$ & $.153^{\star *}$ & $.285^{\star \star}$ & 1 & .060 & $-.181^{\star \star}$ & $-.452^{\star \star}$ & -.021 \\
\hline & $\begin{array}{l}\text { Sig. (2- } \\
\text { tailed) }\end{array}$ & .008 & .000 & & .300 & .002 & .000 & .716 \\
\hline & $\mathrm{N}$ & 300 & 300 & 300 & 300 & 300 & 300 & 300 \\
\hline \multirow[t]{3}{*}{$\begin{array}{l}\text { Reduction in } \\
\text { Tax Rate }\end{array}$} & $\begin{array}{l}\text { Pearson } \\
\text { Corr. }\end{array}$ & $.257^{\star \star}$ & $.132^{*}$ & .060 & 1 & $.264^{\star *}$ & .045 & .017 \\
\hline & $\begin{array}{l}\text { Sig. (2- } \\
\text { tailed) }\end{array}$ & .000 & .022 & .300 & & .000 & .440 & .768 \\
\hline & $\mathrm{N}$ & 300 & 300 & 300 & 300 & 300 & 300 & 300 \\
\hline \multirow[t]{3}{*}{$\begin{array}{l}\text { Accelerated } \\
\text { Dep }\end{array}$} & $\begin{array}{l}\text { Pearson } \\
\text { Corr. }\end{array}$ & .067 & .064 & $-.181^{\star \star}$ & $.264^{\star *}$ & 1 & .005 & $-.184 \star \star$ \\
\hline & $\begin{array}{l}\text { Sig. (2- } \\
\text { tailed) }\end{array}$ & .249 & .266 & .002 & .000 & & .933 & .001 \\
\hline & $\mathrm{N}$ & 300 & 300 & 300 & 300 & 300 & 300 & 300 \\
\hline \multirow[t]{3}{*}{$\begin{array}{l}\text { Loss Carry } \\
\text { Forward }\end{array}$} & $\begin{array}{l}\text { Pearson } \\
\text { Corr. }\end{array}$ & $.352^{\star \star}$ & $-.129^{*}$ & $-.452^{\star *}$ & .045 & .005 & 1 & $.399 * \star$ \\
\hline & $\begin{array}{l}\text { Sig. (2- } \\
\text { tailed) }\end{array}$ & .000 & .026 & .000 & .440 & .933 & & .000 \\
\hline & $\mathrm{N}$ & 300 & 300 & 300 & 300 & 300 & 300 & 300 \\
\hline \multirow{3}{*}{$\begin{array}{l}\text { Tax } \\
\text { exemption }\end{array}$} & Pearson & $.368^{\star \star}$ & $-.262^{\star \star}$ & -.021 & .017 & $-.184^{\star \star}$ & $.399 * \star$ & 1 \\
\hline & $\begin{array}{l}\text { Sig. (2- } \\
\text { tailed) }\end{array}$ & .000 & .000 & .716 & .768 & .001 & .000 & \\
\hline & $\mathrm{N}$ & 300 & 300 & 300 & 300 & 300 & 300 & 300 \\
\hline
\end{tabular}

Source: Survey data, 2020

With regards to the relationship between dependent variable sustainability of MSMEs and independent variables with coefficient of correlation 1 indicates that each variable is perfectly correlated with each other. The result shows that tax holiday, tax allowance, reduction in tax rate, accelerated depreciation, loss carries forward and tax exemption were positive and significantly correlated with sustainability at $1 \%$ level of significance. 
Ordinary Least Squares (OLS) is the most common estimation method for linear models and that's true for a good reason. As long as your model satisfies the OLS assumptions for linear regression, we can rest easy knowing that we're getting the best possible estimates. The most common assumptions to be tested before running final regression result are normality, multicollinearity, autocorrelation, and heteroscedasticity have been checked and confirmed.

\section{The Regression Results (Inferential Statistics)}

\section{Table 5: Regression Results}

\begin{tabular}{|c|c|c|c|c|c|c|c|c|c|c|}
\hline \multirow{2}{*}{\multicolumn{2}{|c|}{$\begin{array}{l}\mathrm{R}=.687 \\
=0.000 \\
\text { Model }\end{array}$}} & \multicolumn{2}{|c|}{$\begin{array}{l}\text { Unstandardized } \\
\text { Coefficients }\end{array}$} & \multirow{2}{*}{$\begin{array}{l}\text { Standardized } \\
\text { Coefficients } \\
\text { Beta }\end{array}$} & \multirow[t]{2}{*}{$\mathrm{T}$} & \multirow[t]{2}{*}{ Sig. } & \multicolumn{2}{|c|}{$\begin{array}{l}95.0 \% \\
\text { Confidence } \\
\text { Interval for B }\end{array}$} & \multicolumn{2}{|l|}{$\begin{array}{l}\text { Collinearity } \\
\text { Statistics }\end{array}$} \\
\hline & & B & $\begin{array}{l}\text { Std. } \\
\text { Error }\end{array}$ & & & & $\begin{array}{l}\text { Lower } \\
\text { Bound }\end{array}$ & $\begin{array}{l}\text { Upper } \\
\text { Bound }\end{array}$ & Tolerance & VIF \\
\hline \multirow[t]{7}{*}{1} & (Constant) & -2.378 & .378 & & -6.285 & .000 & -3.123 & -1.633 & & \\
\hline & Tax holiday & .433 & .050 & .401 & 8.578 & $.000^{\star \star \star}$ & .333 & .532 & .824 & 1.214 \\
\hline & $\begin{array}{l}\text { Tax } \\
\text { Allowance }\end{array}$ & .199 & .047 & .217 & 4.139 & $.000 * \star \star *$ & .103 & .290 & .658 & 1.519 \\
\hline & $\begin{array}{l}\text { Reduction in } \\
\text { Tax Rate }\end{array}$ & .178 & .056 & .141 & 3.136 & $.002^{\star \star \star}$ & .065 & .285 & .897 & 1.115 \\
\hline & $\begin{array}{l}\text { Accelerated } \\
\text { Dep }\end{array}$ & .170 & .073 & .107 & 2.314 & .021 & .025 & .314 & .852 & 1.174 \\
\hline & $\begin{array}{l}\text { Loss Carry } \\
\text { Forward }\end{array}$ & .341 & .052 & .353 & 6.594 & $.000^{\star \star \star}$ & .240 & .443 & .629 & 1.590 \\
\hline & $\begin{array}{l}\text { Tax } \\
\text { exemption }\end{array}$ & .441 & .062 & .355 & 7.088 & .000 & .318 & .563 & .720 & 1.388 \\
\hline
\end{tabular}

Source: Survey data, 2020

\section{Fitted Model}

Sustainability of MSMEs $=-2.378+0.433 *$ Tax holiday $+0.199 *$ tax allowance $+0.179 *$ reduction in tax rate +0.170 * accelerated Dep $+0.431 *$ loss carry forward +0.441 tax exemption + e... (1)

The OLS result was presented in the above table 4.6. R-squared was measured the goodness of fit of the explanatory variables in explaining the variations in employees motivation. The Adjusted-R- squared statistics of the model was 46.1 percent. The result indicates that 45.6 percent variation in the dependent variable was jointly explained by the explanatory variables in the model. Whereas, the remaining 53.9 percent of the variation in the growth of Micro, small and medium sized enterprises (as measured by Likert scale) explained by other variables which are not included in the model. The coefficient of explanatory variables such as tax holiday 0.433 , tax allowance 0.199 , reduction in tax rate 0.178 , accelerated deprecation 0.170 , loss carryforward 0.341 , tax exemption 0.441 implies that $1 \%$ increase in the variables leads to $43.3 \%, 19.9 \%, 17.8 \%, 17 \%, 34.1 \%$ and $44.1 \%$ increase in sustainability of MSMEs during outbreak of corona virus in Ethiopia. Besides, the, F-statistics (43.583) in model summary and ANOVA with ( $p$-value of 0.000 ) which is used to test the overall significance of the model was 
presented and indicates the reliability and validity of the model at 1 percent level of significance. This tells us that the model as a whole is statistically significant.

Tax Holiday: A tax holiday is a government incentive program that offers a tax reduction or elimination to businesses tax that help stimulate business sustainability. The result of this study shows that tax holiday with coefficient of regression [b=0.433] has positive and statistically significant effect on the growth of MSMEs at $1 \%$ level of significance since ( $p$-value of $0.000>$ 0.01). Hence, hypothesis $\mathrm{H} 1$ is accepted. This finding is consistent the finding of other studies results Samuel (2015) and Twesige and Gasheja (2019); A.Akanbi. (2020); Atawodi O.W. \& Ojeka1.S.(2012) who increase in business tax holiday has a positive and significant impacts on sustainability of micro, small and medium sized enterprises operating in Ethiopia. Also, the idea was supported by ideas of New Growth theory and Laffer curve theory. This implies that existence of tax holiday enhances the sustainability of micro, small and medium sized enterprises operating in Ethiopia.

Tax Allowance: Tax allowance refers to an exemption income tax an micro, small and medium sized enterprises pay to government for example in Ethiopia for enterprises registered as solepropiritership and partnership form of business annual business income up to 7,200 ETB is exempted from business income tax. In this study, the coefficient of regression tax allowance, $[b=0.199]$ is positive and statistically significant at $1 \%$ level of significance with ( $p$-value of $0.000>1 \%$ ). Therefore, hypothesis $\mathrm{H} 2$ stated is accepted. This finding is consistent with that of with general logic that existence tax freedom enables to accumulate capital since there is no annual payments to the government. It is also consistent with empirical findings of Twesige and Gasheja (2019), Atawodi O.W. \& Ojeka1.S.(2012); Schellhase J. (2017); IMF (2009); Siyanbola et al (2017); A.Akanbi. (2020), Oniha. K. (2018); Atawodi \& Ojeka (2012), Mungaya (2012), Atawodi O.W. \& Ojeka1.S.(2012); Damtew. M. (2014); Kassahun .S. (2016), N. Francis. (2016); and Laffer curve theory \& New Growth theories evidenced that tax allowance has positive and significant effect on sustainability of micro, small and medium sized enterprises.

Reduction in Tax Rate: lowering taxes raises disposable income, allowing the consumer to spend additional sums, thereby increasing GNP. Reducing taxes thus pushes out the aggregate demand curve as consumers demand for more goods and services provided by micro, small and medium sized enterprises with their higher disposable incomes. In this study reduction in tax rate boosts growth of SMEs. The result of coefficient of $[b=0.178]$ which is positive and statistically significant at $1 \%$ level of significance because the sig of 0.002 is less than $1 \%$. Hence, the $\mathrm{H} 3$ is accepted. This finding is consistent with empirical findings of Atawodi O.W. \& Ojeka1.S.(2012); Damtew. M. (2014); Kassahun .S. (2016), N. N. Francis. (2016); Eliyas. M. (2016), Kassahun. S. (2015); Twesige and Gasheja. (2019) and the idea of Laffer curve theory \& New Growth theory. This tells us tax reduction has higher contribution tax sustainability of MSMEs.

Accelerated depreciation: For tax purposes, accelerated depreciation provides a way of deferring corporate income taxes by reducing taxable income in current years, in exchange for increased taxable income in future years. This is a valuable tax incentive that encourages businesses to purchase new assets. In this study, accelerated depreciation variable has coefficient of regression is $[b=0.170]$ is positive and statistically significant with ( $p$-value of 0.021$)$ which is significant at $5 \%$ level of significances. Therefore, hypothesis $\mathrm{H} 4$ is accepted. This finding is consistent with regression results of studies by Twesige and Gasheja (2019); Schellhase J, 2017; Atawodi O.W. \& Ojeka1.S.(2012); A.Akanbi. (2020); Oniha. K. (2018; and ideas of Laffer curve theory \& New Growth theory that suggest that considering the higher amount of accelerated depreciation amount from income tax has positive effect on sustainability of MSMEs in Ethiopia.

Loss Carry Forward: A loss carryforward refers to an accounting technique that applies the current year's net operating loss (NOL) to future years' net income to reduce tax liability.... This results in lower taxable income in positive NOI years, reducing the amount the company owes the government in taxes. Accordingly, the result of this study shows that increase in loss carry forward with coefficient of regression $[b=0.341]$ has positive and statistically significant at $5 \%$ level of significance since ( $p$ value of $0.0 .00<1 \%$ level of significances). Hence, hypothesis $\mathrm{H} 5$ is accepted. The result is similar with findings of Twesige and Gasheja, 2019; J. Schellhase, (2017); A.Akanbi. (2020). Atawodi O.W. \& Ojeka1.S.(2012); Oniha. K. (2018; Damtew. M. (2014); Wangeci and Kaplelach (2018) and ideas of New Growth, Neoclassical and Laffer curve theories and Laffer curve theory which concluded that loss carry forward has positive and significant effect on sustainability of MSMEs.

Page $12 / 16$ 
Tax exemption: A tax exemption is the right to exclude all or some income from taxation by federal or states governments. Most taxpayers are entitled to various exemptions to reduce their taxable income, and certain individuals and organizations are completely exempt from paying taxes. In this study, the unstandardized coefficient of regression of variable is $[b=0.441]$ is positive and significant effect on sustainability of MSMEs with p-value $(0.000>1 \%$, and $5 \%$ level of significance. Therefore, hypothesis $\mathrm{H}_{6}$ is accepted by the researcher. This finding is consistent with the empirical result of Gasheja (2019). Schellhase J. (2017); Atawodi O.W. \& Ojeka1.S.(2012); Eliyas. M.(2016); Oniha K. (2018; Kassahun S.;Damtew. M. (2014) and ideas of New Growth, Neoclassical and Laffer curve theories and Laffer curve theory. This implies that tax exemption for MSMEs has positive contribution to sustainability of MSMEs.

\section{Conclusion}

In this paper, the researchers explored the effect of tax incentive parameters such as tax holiday, tax allowance, tax reduction, accelerated depreciation and loss carry forward on the sustainability of MSMEs. By keeping this objective in mind, the researcher collected the primary data through self-administrated questionnaire and analyzed through SPSS version 21 . The conclusion that can be drawn from the findings was that hypotheses one up to five hypotheses $(H 1, H 2, H 3, H 4, H 5$ and $H 6)$ have been accepted by researchers. This tell us an increase one-unit value the of tax holiday, tax allowance, and reduction in tax rate, accelerated depreciation, loss carry forward and tax exemption were leads to an increase in business sustainability of MSMEs. This means the existence of tax incentive practices promote the sustainability and growth of micro, small and medium sized enterprises. Hence, it is better for government of Ethiopia use adopt additional tax incentive practices in order to enhance the sustainability of MSMEs by reducing the negative effect of COVID-19 pandemic effect. This helps the micro, small scale and medium sized enterprises to improve their business and promote the economic development of the nation while minimizing the diverse effect of corona virus on survival and growth of MSMEs.

\section{Further Research Direction.}

No study is free of limitation; accordingly, there are limitations in the current study. Basically it was focused on effects of tax incentives on the growth of MSMEs in Ethiopia level. Hence, the study can be enhanced if it is done at continental, and global level and also it is possible if it is done on women entrepreneurs' counterpart, the men entrepreneurs by using different methodology and sampling technique. Further research can also incorporate additional variable other than tax incentive and like non-tax incentives together on the growth of MSME since the current variables explained about $46.1 \%$ and the remaining $53.9 \%$ variation on the growth of MSEs that was not incorporated in the current study. The impact of Covid-19 pandemic on the on overall performance of MSMEs should be further investigated with combination of tax incentives and non-tax incentives to be more confident on the study.

\section{Abbreviations}

MSMEs: Micro, Small and Medium Sized Enterprises

ILO: International Labor Organizations

\section{Declarations}

\section{Availability of data and materials}

The data is included in the manuscript.

\section{Competing interests}

The authors declares that there are no competing interests.

\section{Acknowledgements}


We are very honorable to appreciate Dilla University and Pharma College, which are best education institutions in Ethiopia that striving to serve the community and supporting problem solving researches thoroughly. Our pleasant thanks also go to the editors and the anonymous reviewers for their guidance in developing this research paper.

\section{Ethics approval and consent to participate}

Not applicable since this research did not involve human subject.

\section{Consent for publication}

Not applicable.

\section{Author's Contributions}

We have carried out all the whole works of the study. We designed the study research design and carried out the field work, document analysis, literature work, manuscript draft, and editorial. The authors, Bekele Youna and Kanbiro Orkaido, personally undertook this study. The authors also read and approved the final manuscript.

\section{Funding}

This study was conducted by the author finance only. There is no any financial support from any organization.

\section{Authors' information}

Dr. Bekele Youna Beriso has earned BA degree in economics, MSC in pharmacy, PhD in Technology of medicines, pharmacy management, economics and law. He was currently working as lecturer and researcher in pharmacy department, Pharma College.

Mr. Kanbiro Orkaido Deyganto has earned BA degree in Accounting \& Finance, and MBA Specilizing in Finance. Currently he was working at Dilla University as lecturer and researcher in department of Accounting and Finance.

\section{References}

1. A.Akanbi. (2020). The Impact of Tax Collection and Incentives on Economic Growth: Evidence from Nigeria. International Journal of Economics, Finance and Management Sciences. Vol. 9, No. 4, pp. 170-175. doi: 10.11648/j.ijber.20200904.12

2. Atawodi O.W. \& Ojeka1.S.(2012).Relationship between Tax Policy, Growth of SMEs and the Nigerian Economy. International Journal of Business and Management; Vol. 7, No. 13; 2012

3. Center for Disease Control and Prevention Report. (2020) Retrieved from: https://www.cdc.gov/coronavirus/2019ncov/faq.html

4. Economic and Social Commission for Asia and the Pacific. (2017). Tax incentives and tax base protection in developing countries. PP 1-40

5. Economic Commission for Africa. (2020). Economic Impact of the COVID- 19 Report on Africa. Addis Ababa, Ethiopia

6. Feyitimi, O. A., Temitope, L. B., Akeem, \& O. S. Oladele (2016). Tax Incentives and the Growth of Small and Medium Scale Enterprises in Developing Economy: The Nigerian Experience. European Journal of Research and Reflection in Management Science, 4 (2), 24-42

7. Francis. (2016). State Tax Incentives for Economic Development. Economic Development Strategies, Information Brief 3. PP 1-9

8. Gokhberg L., Kitova G., Roud V. (2014). Tax Incentives for R\&D and Innovation: Demand vs. Effects. Foresight-Russia, vol. 8, no 3, pp. 18-41. 
9. International Labor Organizations. (2020). as job losses escalate, nearly half of global workforce at risk of losing livelihoods. Retrieved from http://ilo.org/global/about-the-ilo/newsroom/news/WCMS_743036/lang-en/index.html

10. Schellhase. (2017). Promoting Participation in SME Boards through Tax Incentives: A Global Overview. Milken Institute Center for Financial Markets. PP 1-12

11. Oniha K. .(2018). Evaluation of Tax Incentives On Growth And Development Of Selected Small And Medium Scale Enterprises In Nigeria. Senior essay

12. Fantaye. K. (2016) Factors Influencing The Performance Of Micro And Small Enterprises In Addis Ababa: Study Of Selected Mse In Bole Sub City. Mba Thesis.

13. Lemi. M. Bogale. \& W. Mengesha. (2020). The Effect of COVID -19 on Micro, Small and Medium Enterprises' Operation in Ethiopia. Horn of Africa Journal of Business and Economics (HAJBE), Special Issue I, PP: 10-17. Riterived from http://journals.ju.edu.et

14. M.I., Latif. Rahman. H. Ahmad. H. Ahmad. F. Khurshid. M.M. Shafique, M.N. (2019). Estimation of Laffer curve: Evidence from Pakistan. 5(1). PP 103-112.

15. Twesige D. and F. Gasheja. (2019). Effect of tax incentives on the growth of small and medium-sized enterprises (SMEs) in Rwanda: A case study of SMEs in Nyarugenge district. Journal of Accounting and Taxation. Vol. (11(5), pp. 89-98.

16. Organization for economic co-operation and Development.(2020). Coronavirus (COVID-19): SME Policy Responses. Talking corona virus-browse OECD contribution available online at http://www.oecd.org/termsandconditions/ accessed on October 21,2020

17. Olana, $D$ R, (2020). The Effect of Covid-19 on SMEs and Entrepreneurial Resilience in Ethiopia. A Case of Nekemte Town. Research on Humanities and Social Sciences. Vol.10, No.11, pp. 1-5

18. Kassahun. S. (2016). the Impacts Of Tax Incentives In Attracting Foreign Direct Investement In Ethiopia. MSC thesis

19. Eliyas. M.(2016). effect of tax incentive on domestic investment in Ethiopia: a case study in the manufacturing sector.

20. Damtew. M. (2014). Effectiveness of Tax Incentive in Promoting Investment in Ethiopia. MBA thesis

21. Ministry of Health. (2020). Ministry of Health COVID update report [Online] (Updated May 06, 2020). Retrieved from: http://www.moh.gov.et/ejcc/

22. Melese. D. (2013). Investment Incentives in Ethiopia. Retrieved from.https://www.2merkato.com/articles/investment/2480-investment-incentives-in-ethiopia

23. Mungaya. M, Andrew H. Mbwambo, Shiv K. Tripathi .(2012). Study of Tax System Impact on the Growth of Small and Medium Enterprises (SMEs): With Reference to Shinyanga Municipality, Tanzania. International Journal of Management \& Business Studies IJMBS

24. Munongo, S., Akanbi, O. A., Robinson, Z. (2017). Do tax incentives matter for investment? A literature review. Business and Economic Horizons, 13(2), 152-168, http://dx.doi.org/10.15208/beh.2017.12Vol. 2, Iss ue 3, pp 99-105

25. Wangeci M. \& Kaplelach. S. (2018). Taxation and The Growth Of Small And Medium Enterprises In Voi Sub County, Kenya. International Journal of Economics, Commerce and Management United Kingdom Vol. VI, Issue 5, PP. 871-874

26. World Health Organization. (2020).World Health Organization Declares COVID-19 a 'Pandemic.' Available on https://www.google.com/url?

27. Yamane, T. (1967). Statistics: An Introductory Analysis, 2nd Edition, New. Avialable on https://www.google.com/url?

28. Yadav J., and Gulati N, (2019). SWOT Analysis of Micro Entrepreneurship and Start-ups in Haryana, International Journal of Business and Economics Research. Vol. 8, No. 6, 2019, pp. 399-405. doi: 10.11648/j.ijber.20190806.20

\section{Figures}




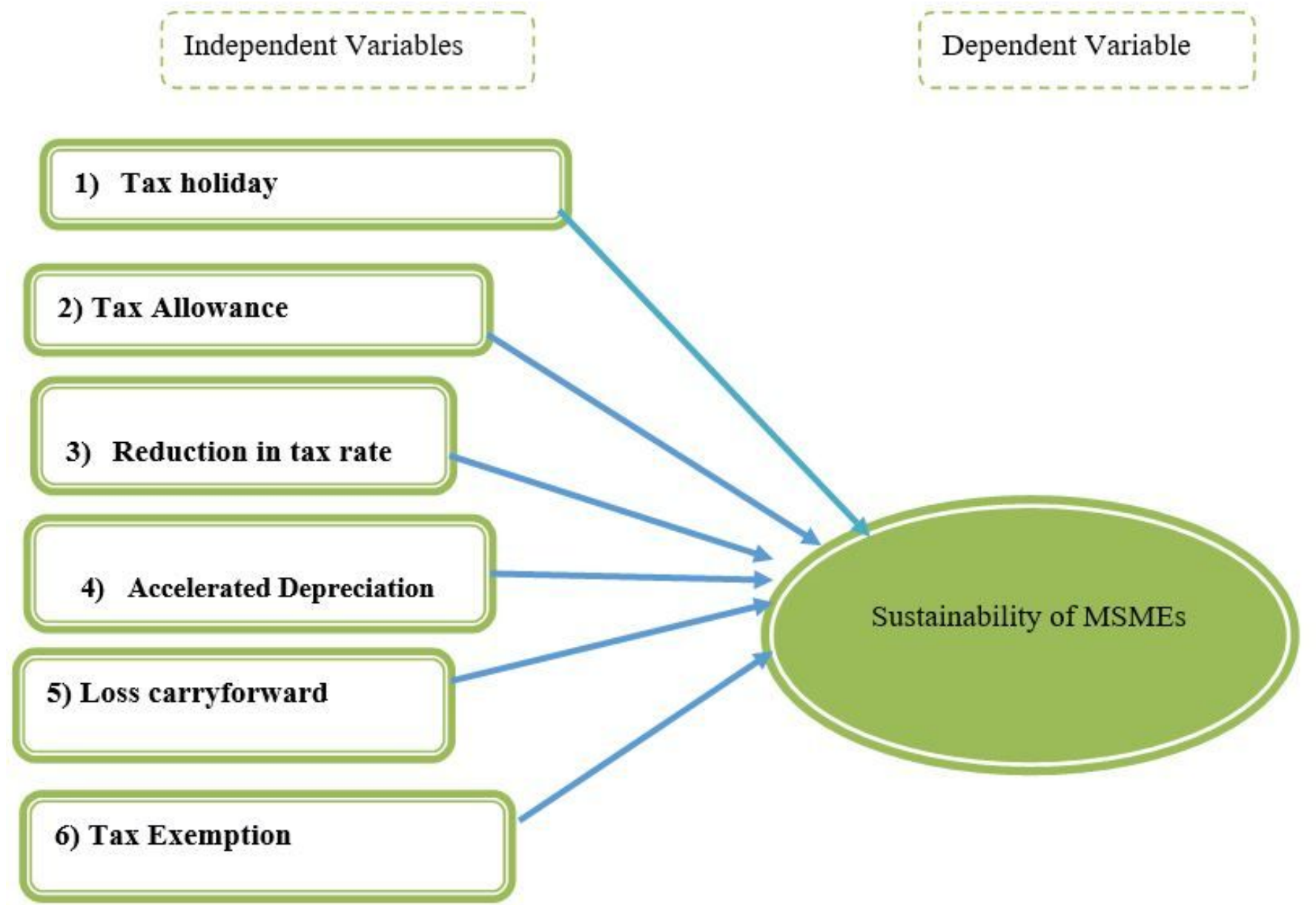

Figure 1

Conceptual Framework Source: Own development based on literature review (2020) 